\title{
14. The Issue of Land in China's Urbanisation and Growth Model
}

Tao Ran

\section{Introduction}

Land reform is a key part of contemporary China's economic transition and development. The reform and opening-up process in China was initiated from rural land reform in the late 1970s and the early 1980s. With the introduction of the Household Responsibility System (HRS) in the early reform period, agriculture shifted from a collective-based farming system to a family-based one. This brought about robust growth in agricultural output and farmers' incomes throughout the first half of the 1980s. Rural land reform also laid a solid foundation for the rapid growth of township and village enterprises (TVEs). Without the success of rural land reform as the first push, one cannot even imagine the subsequent reforms in urban China that have generated the nearly double-digit growth rate of the past three decades. One also would not have thought China could shift from a closed planned economy to an increasingly open market economy.

Since the early 2000s, in particular after China's accession into the World Trade Organisation in 2001, China's economic growth has entered a new phase. There has been a consensus in Chinese academia and policy circles that industrialisation, urbanisation and globalisation have been the driving forces behind China's robust growth in this period. It was in this period that landrelated issues became prominent as China experienced rapid urbanisation and industrialisation.

First, for industrialisation and urbanisation to occur, there needs to be conversion of agricultural land that allows the building of factories and urban housing and infrastructure. This involves the displacement of farmers from land around the cities in the process of urbanisation. Second, as industrialisation and urbanisation proceed, a set of institutions is needed to encourage farmers to move from rural to urban areas and from agriculture to manufacturing and service sectors. This requires a way to finance such migration and support the migrating farmers throughout what is inherently a risky process (Todaro 1969; Stark 1991). Land is an important element here since it is indispensible for providing decent and affordable housing for migrants so they can settle in 
cities on a permanent basis. Finally, since the process of industrialisation and urbanisation is a gradual and long one, the system must allow those who are left behind in the first wave of migration to be able to access resources so they can get themselves ready to move in either this or even the next generation (Johnston and Mellor 1961).

Precisely because there are inherent weaknesses in China's land system, landrelated issues in China's rapid urbanisation have become increasingly acute in the past decade. Under the current land requisition system, rapid urbanisation has led to tens of millions of dispossessed farmers being left undercompensated. Under the current rural construction land management system, farmers are legally disallowed from developing their own land for non-agricultural purposes. This makes the provision of affordable housing with decent living conditions extremely difficult. The hundreds of millions of rural migrants have to live either in employer-provided dorms or in the 'urban villages' with poor planning and infrastructure. Unable to settle in cities on a permanent basis, the large numbers of migrants who are already earning most of their incomes in the cities and are unwilling to return to the countryside are still unwilling to give up their agricultural land. This, in turn, makes it difficult for those who are left behind in the countryside to expand their scale of agricultural production.

This chapter aims to analyse the main challenges in China's current land system and propose a reform package to address these challenges. The rest of the chapter proceeds as follows. In section two, we discuss the role of land as a key policy instrument employed by Chinese local governments in industrialisation and urban development. In section three, we discuss the distortions coming from China's current land management system. In section four, we introduce the current reform initiatives both at the central and at the local levels, and analyse why they are inadequate to improve land-use efficiency and to bring social justice to the countryside. In section five, we will propose an integrated reform package that includes land, hukou and fiscal reforms to help China complete its economic transition. Section six concludes.

\section{Instrumental use of land in China's urbanisation and local development}

Land became a key instrument in China's local economic development after the mid 1990s. This had to do with a major change in central-local relations - that is, the 1994 tax-sharing reform. The 1994 tax reform raised the Central Government's share of government revenues (World Bank 2002). Local governments, on the other hand, found their share shrinking in the late 1990s and early 2000s. A further hit to local public finance in the mid 1990s 
was large-scale restructuring and privatisation of local government-owned enterprises and TVEs that contributed a great deal to local revenues in the 1980s and the early 1990s. As industrial overcapacity emerged in manufacturing by the mid 1990s, it became clear that SOEs and TVEs, instead of being a tremendous asset, had become a liability for many local governments. To save them from endless drains on their finances, regional governments initiated the privatisation of small SOEs. When the new century dawned, the majority of SOEs and TVEs in the country had completed their transformation (Qian 2000).

As a result of these changes, local governments metamorphosed from asset owners to tax collectors. This redefinition of the state's role had powerful impacts on local governments' behaviour. As asset owners, local officials had strong incentives to support their own 'children' and ensure their profitability. Being tax collectors, however, they had to cater to all potential tax contributors. Alongside more efficient and profitable domestic private enterprises, foreign firms started to enter China en masse in the second half of the 1990s. Unlike SOEs and TVEs, these firms were mobile and were more responsive to local policy incentives. They would relocate to another jurisdiction if it offered more favourable tax deductions and better infrastructure. Local governments had to compete fiercely to grow their tax bases.

Fiscal centralisation and privatisation worked together to exacerbate the fiscal strain on local governments. As a result, local governments' resources could not keep up with their increasing fiscal obligations, including supporting retirees and laid-off workers from former SOEs and fulfilling various unfunded mandates from the centre (Tsui and Wang 2004). To make up for the revenue shortfalls, local governments gradually discovered the value of land. Cheap land now became a key instrument in regional competition for mobile tax bases. As the de facto owners of urban land, local governments could sell land-use rights to industrial investors for 50 years, businesses for 40 years and residential housing for 70 years. During the 2000s, land leasing fees grew rapidly and now constitute a large part of local fiscal revenues. What is more, when urban land was used up, local officials had the legal authority to convert farmland. Therefore, local revenues would grow with urbanisation. Since then, requisitioning farmland, leasing land and managing urban expansion have become the main business of China's local governments.

Local officials were particularly keen on attracting industrial land users for revenue reasons. In terms of taxes, manufacturing businesses mainly generate two kinds of revenue for local governments - that is, value-added taxes (VATs) and enterprise income taxes. Ultimately, only 25 per cent of VATs and 40 per cent of enterprise income taxes will stay locally; however, it has become common practice since the late 1990s for regional authorities to rebate all enterprise income taxes for the first three years and half in the next two years. 
Moreover, in order for the enterprises to settle in their jurisdictions, localities must spend a large amount of financial resources on basic infrastructure, including land, roads, water and electricity. Nevertheless, because of fierce regional competition, local governments often had to offer manufacturing investors cheap land and sometimes they even leased land to industrial investors free of charge. The questions that naturally follow are why is manufacturing so desirable? How can local governments secure other financing to subsidise manufacturing in the short or even medium term? It turns out that local governments have developed a clever strategy to exploit this linkage and continue their development (Tao et al. 2009, 2010).

Figure 14.1 sketches a simplified analysis. All localities essentially deal with two kinds of businesses: manufacturers and service providers. As discussed above, manufacturing enterprises bring stable VATs and enterprise income taxes. What appeals to regional governments even more is their ability to spill over and foster service industries. Once factories start to operate, workers and managers living in the cities and towns have the financial means to improve their lives. Services and businesses such as shopping malls, restaurants, entertainment facilities, banks and real estate developers sprout up to cater to the growing needs of these people (Lin and Ho 2005; Tao et al. 2010).

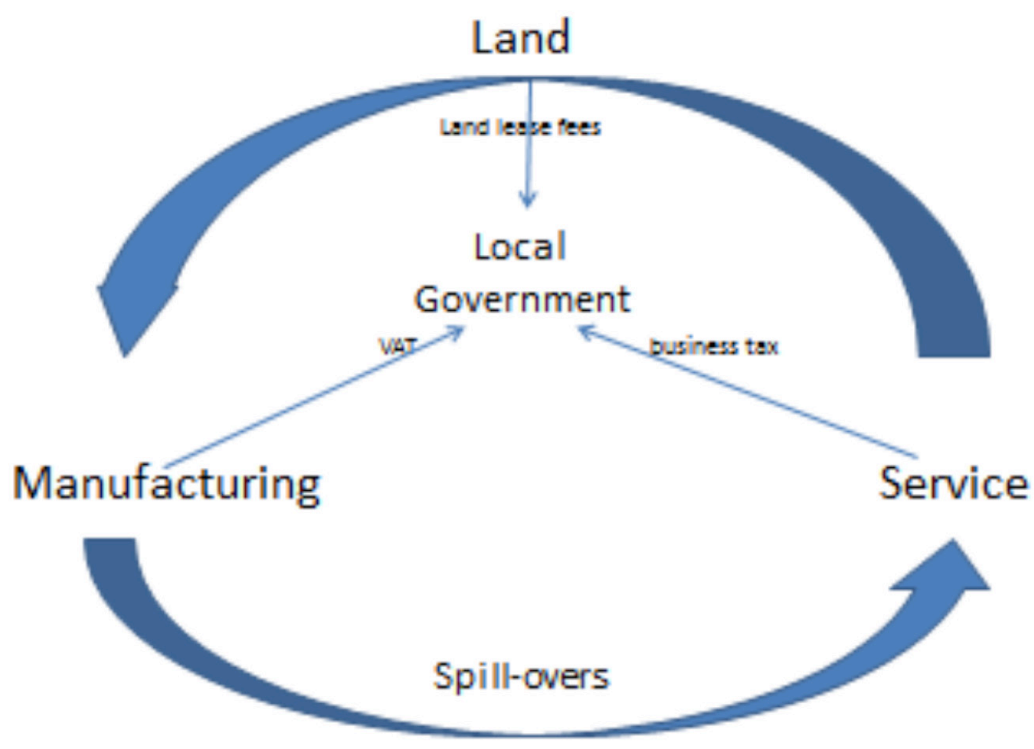

Figure 14.1 Local Government Development Strategy: Manufacturing, Services and Land 
In recent years, we have conducted many interviews on local development practices and, almost without exception, local officials emphasised the importance in their decision-making of industrial spillovers from manufacturing to services. Therefore, from a revenue perspective, manufacturing not only generates VATs and enterprise income taxes directly, but also contributes to growing business tax - a tax assigned solely to local governments. Since manufacturing growth can stimulate local service sectors that generate handsome business taxes and land leasing fees, subsidising manufacturing land is worthwhile. In particular, significant profits can be generated by more competitive public auctions of commercial/residential land.

The past decade also witnessed a gradual geographical expansion of land developmentalism. Initially, in the late 1990s, large-scale industrial park and urban construction unfolded in coastal areas. Since the early and mid 2000s, inland areas have started to catch up in this industrialisation and urbanisation drive (Lin 2007). Inland localities did not join the regional manufacturing competition in the beginning due to relatively poor endowments such as infrastructure. As their infrastructure began to improve, inland regions were finally ready to compete for investment. Another equally important factor was the rural tax reform introduced between 2002 and 2006, which caused severe revenue shortfalls among inland governments. The rural tax reform deprived local governments in agriculture-based inland regions of the right to collect revenue from agriculture through formal taxes and informal charges. Unable to continue revenue collection from agriculture, local governments in inland China had to engage in fierce regional manufacturing competition in this period.

In hindsight, the emergence of land developmentalism was not an accident, but a natural outcome of China's unique land regulatory regime after fiscal recentralisation in the mid 1990s. Here China's land requisition system under which local governments have monopolistic control over land conversion from rural to urban use played a pivotal role. Local governments are de facto owners of all urban land in their jurisdictions. They can determine how land is used and collect revenue from leasing land-use rights on the market. Land in rural areas, on the other hand, is owned by rural collectives. Therefore, in each locality, there are two parallel land ownership regimes and only local governments have the power to cross this line and convert rural land to urban use. It is illegal and strictly forbidden for village collectives to directly lease land to urban users (Lin 2007; Zhu and Prosterman 2007; World Bank 2005; Lin and Ho 2005). This de facto regional monopoly of land supply allows local officials to discriminate against certain land users and leverage land for development. Local governments were found to strategically limit the amount of land for commercial and real estate businesses in their jurisdictions so prices would continue to rise 
(Tao et al. 2010; Lin and Yi 2011; Wu 2010). Service businesses had no choice but to pay local governments high land-lease fees. Because limited land supply weakened competition, service providers passed the costs on to local residents. ${ }^{1}$

Under China's current development model, local governments rushed to build more and more industrial parks and development zones. By the end of 2003, the total number of industrial zones and parks had reached 3837. Among them, only 6 per cent (232) had received approval from the Central Government. Provincial governments approved 27 per cent of them (1019). Various city, county and township governments had taken their own initiative to get the majority of these zones (2586) up and running. By 2006, the figure jumped further, to 6015 (Zhai and Xiang 2007) — which was about two industrial parks per county on average. Developing and managing land have become a major business for local governments in many localities.

While comprehensive information about all industrial parks is rare, a government audit report offers a glimpse of the geographic distribution of the parks. In 2006, the Central Government was alarmed by the great-leap mentality among local officials and ordered the National Development and Reform Commission (NDRC), the Ministry of Land and Resources and the Ministry of Construction to launch a full investigation. Table 14.1 groups Chinese provinces into coastal and inland ones and summarises the number of development zones by the approving authority. Of 222 economic development zones, high-tech industrial parks, tariff-free zones and other types of zones approved directly by the State Council, two-thirds were located in coastal provinces. If we look at provincial government decisions, however, the regional imbalance is no longer prominent. Many inland provinces, such as Anhui, Jiangxi, Hubei and Hunan, were not far behind in setting up development zones. Even Gansu, a poor province in the remote western region, established 34 industrial zones, specialising in machinery, construction materials, food processing and chemicals. This audit did not cover development zones and industrial parks approved by municipal and county governments, but it is reasonable to assume the same pattern should hold. Overall, the rush to industrialise originated on the east coast but, by the mid 2000s, had become a national phenomenon and engulfed the whole of officialdom at the local level.

1 Both manufacturing and services create jobs and generate revenue, but they differ in one crucial industrial attribute: location specificity (Tao et al. 2010). Manufacturing enterprises mostly produce tradable goods for the domestic or international market. The tenuous attachment to specific locations enhances their mobility in response to production costs. If other regions provide better conditions, they may relocate their production facilities relatively easily. Service businesses, on the other hand, must establish contacts with local residents to deliver their products. This location rigidity gives local governments the upper hand in bargaining and creates a potential for backward linkage. 
Table 14.1 Development Zones and Industrial Parks by Level of Approval and by Province

\begin{tabular}{|c|c|c|c|c|}
\hline Approval authority & Coastal region & Number & Inland region & Number \\
\hline State Council & & 147 & & 75 \\
\hline \multirow[t]{19}{*}{ Provincial governments } & & 683 & & 663 \\
\hline & Beijing & 16 & Shanxi & 22 \\
\hline & Tianjin & 25 & Inner Mongolia & 39 \\
\hline & Hebei & 45 & Jilin & 35 \\
\hline & Shandong & 155 & Heilongjiang & 29 \\
\hline & Liaoning & 42 & Anhui & 85 \\
\hline & Jiangsu & 109 & Jiangxi & 88 \\
\hline & Shanghai & 26 & Henan & 23 \\
\hline & Zhejiang & 103 & Hubei & 89 \\
\hline & Fujian & 65 & Hunan & 73 \\
\hline & Guangdong & 69 & Chongqing & 34 \\
\hline & Guangxi & 23 & Sichuan & 38 \\
\hline & Hainan & 5 & Guizhou & 13 \\
\hline & & & Yunnan & 15 \\
\hline & & & Shaanxi & 17 \\
\hline & & & Gansu & 34 \\
\hline & & & Qinghai & 3 \\
\hline & & & Ningxia & 15 \\
\hline & & & Xinjiang & 11 \\
\hline
\end{tabular}

Source: NDRC et al. (2006).

After the audit, the Central Government decided to curb the overexcitement among local officials and consolidated development zones or ordered shutdowns in many places. Unable to set up more industrial parks without upper-level approval, most newly established industrial parks simply changed their names and became 'urban industrial functional zones' or 'urban industrial complexes' without any change in real functions. According to the author's observations, the number of industrial parks in operation after the mid 2000s actually increased with extension to areas further inland. This diffusion was further accelerated after the GFC, when the Chinese Government introduced its fiscal and financial stimulus package. As analysed earlier, to make the rapid industrialisation financially viable, rising real estate bubbles soon followed across the country, which gave many local governments in inland areas a fiscal illusion that they could borrow money for more industrial park building and pay it back using the fees through leasing residential and commercial land at higher prices. Manufacturing capacity built up quickly. To find markets for their products, enterprises had to be more aggressive on the international market, leading to ever-rising foreign exchange reserves. 
Since the late 1990s, the fiscally strapped local governments in China have increasingly turned to land (Yang 2004). On the one hand, they lease land to manufacturing investors mostly by negotiation and at subsidised prices. Local governments usually incur a net loss in leasing land for manufacturing users. By providing land at negotiated and usually very low leasing prices, local governments strive to attract industrial investors through a 'site-clearing' style of packaged development. Usually at only nominal prices or even the so-called 'zero price', the prepared land was leased out for 50 years. Since local governments need to finance the land requisition costs (compensation to dispossessed farmers) and infrastructure preparation costs (costs of building roads and providing access to electricity, water, heating, and so on) ex ante, leasing out industrial land at low or even zero prices inevitably means local governments are incurring net losses in the process.

On the other hand, local governments lease most of the commercial and residential land by auction and public tender so as to earn as high extra-budget revenue as possible utilising their monopolistic position in urban land-leasing markets. In practice, almost every city has set up one or several industrial parks that supply cheap land to industrial users while most cities have also set up 'land reserve centres' that prepare land for residential and commercial use, and then auction it off to commercial and residential developers for profit. In many regions, the revenue from land leasing, especially the fees from commercial and residential land leasing, has become the single most important source of local extra-budget revenue. Studies consistently show that land transfer fees account for some 30-50 per cent of total sub-provincial government revenues, and in some developed regions, it amounts to 50-60 per cent of the total city revenue (World Bank 2005).

As Figure 14.2 shows, land-lease fees, as a part of local extra-budgetary income, were about 50 per cent of the formal budget at the provincial level. In some areas, the ratio was as high as 170 per cent. These revenues enabled regional governments to subsidise incentive packages, including cheap land and tax exemptions, to lure footloose manufacturing capital. In 2007 alone, local governments in China made 226500 ha of land available for commercial and industrial use. Of this land, 115300 ha (50.9 per cent of the total land leasedup 20.4 percentage points from 2006) were auctioned off. For the whole year, land sales generated close to RMB1 trillion (RMB913 billion for the JanuaryNovember period), up from RMB767.7 billion in 2006 and only RMB49.2 billion in 2001. Simply put, local authorities have become hooked on land revenue as virtually a 'second budget' (Tao et al. 2010). 


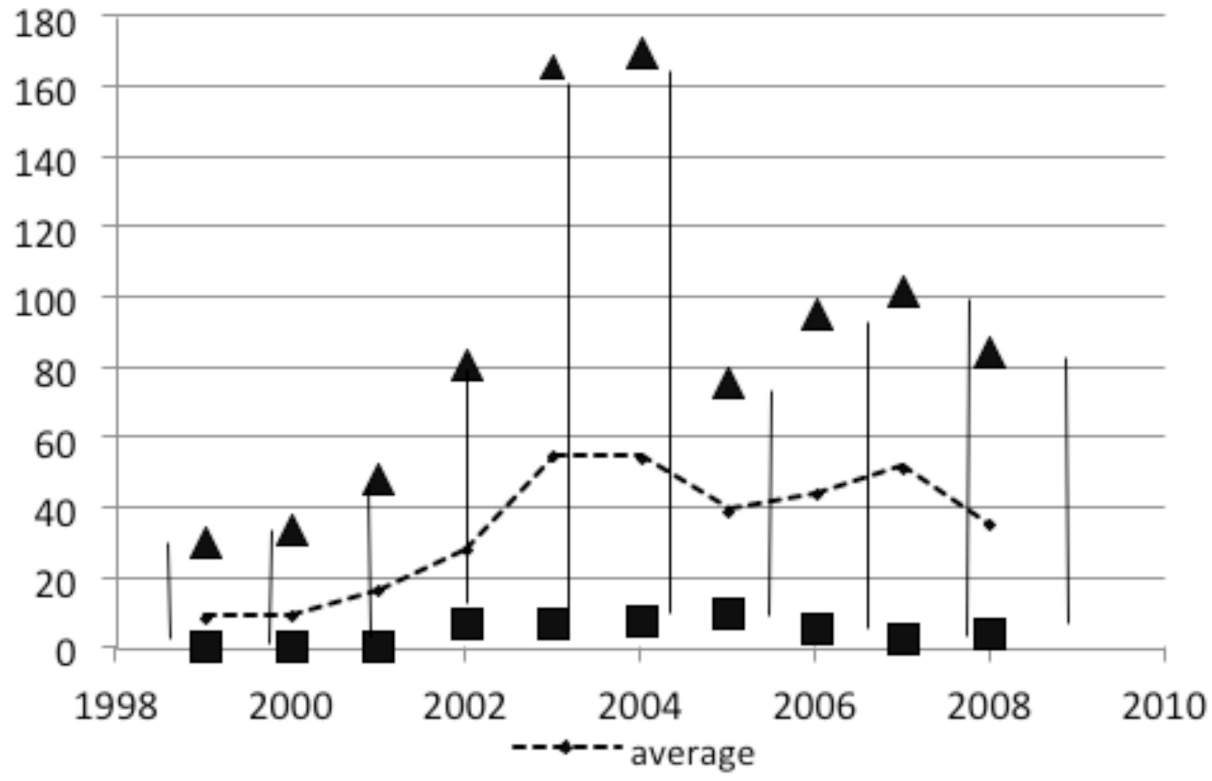

Figure 14.2 Land Lease Fees as a Ratio of Local Budgetary Revenues, 1999-2008 Sources: China Statistical Yearbook and China Land and Resources Statistical Yearbook (NBS various years).

\section{Economic and social distortions resulting from China's land management system}

Analysis of China's current economic growth model is useful in understanding the country's urbanisation model during the same period. It is also helpful to understand the economic and social distortions brought about by this urbanisation model. An instrumental use of cheap land in regional competition for manufacturing for investment has contributed to the investment-driven growth in the past decade. When land as a key production input is underpriced, the overall investment, especially the investment in the manufacturing sector, will be higher than the social optimum. This would lead to an over-industrialised economy as well as relatively low returns on industrial investment.

\section{Imbalance between urbanisation of population and land}

Land-use distortions have also led to an imbalance between China's urban spatial expansion and migration. As shown in Table 14.2, from 2001 to 2008, China's urban population grew at a rapid annual rate of 3.55 per cent, while the average annual growth rate of urban built areas was 6.2 per cent and the 
annual growth rate of urban construction land area was as high as 7.4 per cent. This means the urbanisation of the population has been much slower than the urbanisation of space.

Table 14.2 Comparison of Annual Growth Rates in Urban Populations and Urban Areas under Construction (per cent)

\begin{tabular}{|l|c|c|c|}
\hline Year & Urban population & Urban built area & Area of urban construction land \\
\hline $2001-2005$ & 4.13 & 7.70 & 7.50 \\
\hline $2006-2008$ & 2.57 & 3.73 & 7.23 \\
\hline $2001-2008$ & 3.55 & 6.20 & 7.40 \\
\hline
\end{tabular}

Sources: Based on calculations from NBS $(2008,2009)$.

Notes: Data for urban construction land for Beijing and Shanghai in 2005 are missing. An average value based on data for 2004 and 2006 has been used.

\section{Distortions in land-use structure}

The imbalance in China's urban land-use structure is also serious. Currently, there are $240000 \mathrm{sq} \mathrm{km}$ of construction land in rural and urban China, fivesixths of which is in the countryside owned by rural collectives and used by rural residents. Between 1990 and 2004, the area of urban land in China increased from $13000 \mathrm{sq} \mathrm{km}$ to $39140 \mathrm{sq} \mathrm{km}$, or 155 sq m per capita (Tan and Li 2010). ${ }^{2}$ In cities alone, the area of urban industrial land in 2004 had already reached 7900 sq $\mathrm{km}$ and by 2008 it was 9853 sq km, comprising a full 25 per cent of the total urban construction land, while ecological land made up only 10 per cent and residential land hovered around 31 per cent. The percentages of industrial land area in the more developed cities of Shanghai and Suzhou were as high as 25.77 per cent and 31.79 per cent respectively; however, the global standard for urban industrial land area is usually not more than 10-15 per cent (Huang 2007).

2 In 2004, China had a total village construction land area of 248 million mu. Based on the number of people engaged in agricultural work that year, the per capita area of village land was $217 \mathrm{sq} \mathrm{m}-45.3$ per cent greater than the national limit of 150 sq m per person. 
Table 14.3 Land-Use Ratios in Chinese Cities (2004-09)

\begin{tabular}{|c|c|c|c|c|c|c|}
\hline Sq km/year & 2004 & 2005 & 2006 & 2007 & 2008 & 2009 \\
\hline Urban construction land & 30781 & 29638 & 31766 & 33923 & 36711 & 38727 \\
\hline Residential & 9729 & 9297 & 9772 & 10497 & 11290 & 12056 \\
\hline Public facilities & 3772 & 3704 & 4229 & 4399 & 4678 & 4848 \\
\hline $\begin{array}{l}\text { Industrial and } \\
\text { warehousing }\end{array}$ & 7900 & 7533 & 7998 & 8580 & 9265 & 9853 \\
\hline Transportation & 1717 & 1448 & 1407 & 1498 & 1617 & 1673 \\
\hline Roads and squares & 2989 & 2983 & 3378 & 3668 & 4031 & 4369 \\
\hline Municipal public services & 1053 & 1069 & 1120 & 1164 & 1251 & 1300 \\
\hline Green space & 2856 & 2911 & 3155 & 3404 & 3786 & 3868 \\
\hline Special use & 766 & 694 & 708 & 713 & 794 & 760 \\
\hline Per cent/year & 2004 & 2005 & 2006 & 2007 & 2008 & 2009 \\
\hline Urban construction land & 100 & 100 & 100 & 100 & 100 & 100 \\
\hline Residential & 31.6 & 31.4 & 30.8 & 30.9 & 30.8 & 31.1 \\
\hline Public facilities & 12.3 & 12.5 & 13.3 & 13.0 & 12.7 & 12.5 \\
\hline Industrial & 25.7 & 25.4 & 25.2 & 25.3 & 25.2 & 25.4 \\
\hline Transportation & 5.6 & 4.9 & 4.4 & 4.4 & 4.4 & 4.3 \\
\hline Roads and squares & 9.7 & 10.1 & 10.6 & 10.8 & 11.0 & 11.3 \\
\hline Municipal public services & 3.4 & 3.6 & 3.5 & 3.4 & 3.4 & 3.4 \\
\hline Green space & 9.3 & 9.8 & 9.9 & 10.0 & 10.3 & 10.0 \\
\hline Special use & 2.5 & 2.3 & 2.2 & 2.1 & 2.2 & 2.0 \\
\hline
\end{tabular}

Sources: China Statistical Yearbook for Urban and Rural Construction (NBS various years).

Note: The years 2009, 2008, 2007 and 2006 do not include data for Shanghai; 2005 does not include Shanghai or Beijing.

As shown in Table 14.3, the structure of land use in China's urban areas is highly distorted, with a high share of land going to industrial use, while a relatively low share of land is allocated for use by residential, transportation, green space and service sectors. This is because of the land-lease pricing strategies as discussed above. In 2006, the average price of land in major Chinese cities nationwide was RMB1544 per sq $\mathrm{m}$, with commercial land valued at $\mathrm{RMB} 2480 / \mathrm{sq} \mathrm{m}$, residential land at $\mathrm{RMB1681} / \mathrm{sq} \mathrm{m}$ and industrial land at RMB485/sq m. By 2010, the average price of land nationwide was RMB2882/ sq $\mathrm{m}$, a RMB229 increase over the previous year. A breakdown of this number shows that the price of commercial land was the highest at RMB5185/sq m, followed by residential land at RMB4245/sq $\mathrm{m}$, while the price for industrial land was RMB629/sq m (CASS, respective years).

Industrial land makes up 40-50 per cent of the total new leases every year. Table 14.4 shows that in 2003, 2005 and 2007, China provided 99 400, 90500 and 135600 ha of land for mining, industrial and storage use for each of the respective years, or 51.4 per cent, 54.7 per cent and 57.7 per cent of new urban 
land leases. Between 2003 and 2009, the area of industrial land leased out was 788000 ha -51.3 per cent of the total land leased. The area of residential land and commercial land leased out was only 39100 ha (25.4 per cent) and 198000 ha (12.9 per cent) respectively. As a result, the price of industrial land rose very slowly over these three years, reaching RMB1.25 million, RMB1.38 million and RMB1.56 million per hectare for each respective year, while the price of commercial land rose from RMB3.55 million to RMB6.34 million and to RMB8.71 million per hectare, and the price of residential land was RMB5.98 million, RMB6.8 million and RMB11.31 million per hectare. ${ }^{3}$

\section{Wasteful use of industrial land and the real estate bubble}

The negative impacts of local government land-leasing strategies are obvious. Many cities have constructed 'garden-style factories' that use industrial land very inefficiently. Some industrial companies lease land at an extremely low price and use only part of it, leaving other areas undeveloped, or even carry out large-scale 'greenification' projects on the land.

In 2006, the Ministry of Land and Resources conducted a survey of 124 new industrial projects across 23 key cities around the country. The average landleasing prices for eastern, central and western China were RMB183, RMB264 and RMB265 per sq $\mathrm{m}$ respectively, while the corresponding land requisition costs were RMB463, RMB325 and RMB268 per sq m respectively. That means a subsidy of RMB280, RMB61 and RMB3 per sq $\mathrm{m}$ respectively for eastern, central and western China. ${ }^{4}$

3 Overly high percentages of industrial land use and overly fast growth also exist in medium and small cities. For instance, the average annual increase in industrial land area for the city of Kunshan from 1990 to 2001 was 210.92 ha, which made up half of all the land area under construction and increased annually at a rate of 21.25 per cent. The average increase in industrial land per person was between 40 and $70 \mathrm{sq} \mathrm{m}$ for the cities of Kunshan, Wujiang, Zhangjiawan, Taicang, Yixing and Liyang. On the whole, China's per capita industrial land area has far exceeded the national standard of 15-25 sq m (Huang 2007).

4 Cited from Ministry of Land and Resources (2006). 
Table 14.4 Total Land Area Transferred, Use Ratios and Prices (2003, 2005, 2007)

\begin{tabular}{|c|c|c|c|c|c|}
\hline 2003 & $\begin{array}{l}\text { No. of land } \\
\text { transactions }\end{array}$ & $\begin{array}{c}\text { Total land } \\
\text { area } \\
\text { (ha) }\end{array}$ & $\begin{array}{c}\text { Percentage } \\
\text { of area }\end{array}$ & $\begin{array}{c}\text { Total } \\
\text { transaction } \\
\text { value } \\
\text { (RMB billion) }\end{array}$ & $\begin{array}{c}\text { Unit price } \\
\text { (RMB } \\
\text { million) }\end{array}$ \\
\hline Total & 207387 & 193603 & 100.0 & 542.13 & 2.80 \\
\hline Commercial & 59702 & 39082 & 20.2 & 138.62 & 3.55 \\
\hline Industrial & 58827 & 99435 & 51.4 & 124.73 & 1.25 \\
\hline Infrastructure & 3628 & 5815 & 3.0 & 9.39 & 1.62 \\
\hline Public buildings & 1864 & 2929 & 1.5 & 5.82 & 1.99 \\
\hline Residential & 81487 & 43323 & 22.4 & 258.99 & 5.98 \\
\hline Transportation & 581 & 600 & 0.3 & 1.07 & 1.79 \\
\hline Water services & 128 & 800 & 0.4 & 0.28 & 0.35 \\
\hline Special use & 1170 & 1618 & 0.8 & 3.22 & 1.99 \\
\hline 2005 & $\begin{array}{l}\text { No. of land } \\
\text { transactions }\end{array}$ & $\begin{array}{c}\text { Total land } \\
\text { area } \\
\text { (ha) }\end{array}$ & $\begin{array}{c}\text { Percentage } \\
\text { of area }\end{array}$ & $\begin{array}{c}\text { Total } \\
\text { transaction } \\
\text { value } \\
\text { (RMB billion) }\end{array}$ & $\begin{array}{l}\text { Unit price } \\
\text { (RMB } \\
\text { million) }\end{array}$ \\
\hline Total & 162112 & 165586 & 100.0 & 588.38 & 3.55 \\
\hline Commercial & 34386 & 23268 & 14.1 & 147.41 & 6.34 \\
\hline Industrial & 43027 & 90512 & 54.7 & 125.00 & 1.38 \\
\hline Infrastructure & 2134 & 1994 & 1.2 & 10.67 & 5.35 \\
\hline Public buildings & 1627 & 2436 & 1.5 & 5.86 & 2.41 \\
\hline Residential & 80285 & 43675 & 26.4 & 296.93 & 6.80 \\
\hline Transportation & 161 & 1246 & 0.8 & 1.51 & 1.21 \\
\hline Water services & 311 & 268 & 0.2 & 0.22 & 0.82 \\
\hline Special use & 181 & 2188 & 1.3 & 0.79 & 0.36 \\
\hline 2007 & $\begin{array}{l}\text { No. of land } \\
\text { transactions }\end{array}$ & $\begin{array}{c}\text { Total land } \\
\text { area } \\
\text { (ha) }\end{array}$ & $\begin{array}{c}\text { Percentage } \\
\text { of area }\end{array}$ & $\begin{array}{c}\text { Total } \\
\text { transaction } \\
\text { value } \\
\text { (RMB billion) }\end{array}$ & $\begin{array}{c}\text { Unit price } \\
\text { (RMB } \\
\text { million) }\end{array}$ \\
\hline Total & 160404 & 234961 & 100.0 & 1221.67 & 5.20 \\
\hline Commercial & 25737 & 26975 & 11.5 & 234.95 & 8.71 \\
\hline Industrial & 43477 & 135629 & 57.7 & 211.02 & 1.56 \\
\hline Infrastructure & 1702 & 1454 & 0.6 & 4.83 & 3.32 \\
\hline Public buildings & 1507 & 2121 & 0.9 & 12.01 & 5.66 \\
\hline Residential & 87393 & 66575 & 28.3 & 753.09 & 11.31 \\
\hline Transportation & 411 & 1414 & 0.6 & 4.89 & 3.46 \\
\hline Water services & 127 & 606 & 0.3 & 65 & 1.07 \\
\hline Special use & 50 & 188 & 0.1 & 24 & 1.29 \\
\hline
\end{tabular}

Sources: China National Resources Statistical Yearbook (NBS various years). 
As more and more regions engage in a race to the bottom style of competition for manufacturing investment, the area of industrial land grows rapidly. In 1996, the total area of independent industrial and mining land in China was $27700 \mathrm{sq} \mathrm{km}$. According to the 1997-2010 National Land Use Plan, between 1997 and 2010, the area of independent industrial and mining land could not exceed 33000 sq km by 2010; however, by the end of 2005, the area had already reached $33600 \mathrm{sq} \mathrm{km}$. By the end of 2009, the area increased further, to 43000 sq $\mathrm{km}$ - about 40 per cent of China's urban and industrial/mining land (Xinhua News Agency 2010). In other words, the area of independent industrial and mining land increased by about $15000 \mathrm{sq} \mathrm{km}$ (9 million ha) and the average floor-area ratio was only $0.3-0.4$ - half of the National Government standards.

Contrary to these standards, in order to maximise profits from commercial and residential land, local governments usually undersupply such land and charge a very high land-leasing fee. For example, between 2003 and 2010, more than 15 million mu (100 $000 \mathrm{ha}$ ) of industrial land (43 per cent of total land supply) was leased out with an average land price of RMB97 000/mu, while the area of residential land supplied was only 8.31 million mu (23.6 per cent of the total land supply), with an average land price of RMB560 000/mu (China's National Land Yearbook: NBS various years). The growing real estate bubble in China can also be largely attributed to the instrumental use of land by local governments - that is, oversupply of industrial land and undersupply of residential land. The depressed prices of production factors (including land and workers who lack labour protection or sufficient social insurance) and the relaxed enforcement of environmental protections in China's 'regional raceto-the-bottom' style of competition have resulted in excessive investment in manufacturing sectors and an excessive production capacity that cannot be absorbed by the domestic market. At the same time, the currently low level of compensation for expropriated land and insufficient levels of social insurance have made it difficult for the consumption levels of two major groups - that is, dispossessed farmers and migrant workers - to keep in step with the growth of the overall economy. This further exacerbates the problem of poor domestic demand in the course of China's economic growth.

The need to absorb this accumulated excessive production capacity, encouraged the Government to keep the value of the renminbi artificially low, ensuring excessive production capacity could thus be exported to the international market. Keeping the renminbi artificially low naturally resulted in a trade surplus. The renminbi's inability to appreciate as China's labour productivity grows naturally attracts speculators who believe the renminbi will eventually be forced to appreciate, resulting in a huge influx of hot money into China and therefore the country's ever-rising foreign reserve. In 1995, China had US\$73.6 billion in foreign exchange reserves. By 2000, this had grown to 
US $\$ 165.6$ billion. By 2004, it quickly rose to US $\$ 609.9$ billion. In 2006 , China's foreign reserve was as high as US\$1 trillion, and in April 2009 it exceeded US\$2 trillion. This number exceeded US\$3 trillion in March 2011. China's central bank was forced to release RMB24 trillion to sterilise the foreign reserve, leading to serious excessive liquidity in the economy.

Excessive liquidity naturally flooded into the undersupplied commercial and residential land market and the bubble in the real estate sector emerged. Prior to 2004, the growth of China's housing prices remained slow-below 5 per cent-but housing prices began to shoot up after early 2004, with an annual growth rate of nearly 10 per cent. In order to stabilise the market, the Central Government implemented regulatory policies that mostly focused on managing and standardising land supply. This happened because at the time it was believed that corruption in the land market fostered speculation and resulted in high prices; however, these land market control policies did not address the real problem and housing prices continued to grow at double digit rates. In May 2005, another round of housing price-control policies went into effect. In addition to providing public housing to middle and low-income households, there are articles to punish land speculators, and business tax was also used as a tool to control housing prices. While this did effect a slowing in housing price growth, the rate remained above 5 per cent. Realising that these policies would not control housing prices successfully, the Central Government started to take harsher measures, including forcibly regulating the lowest proportion of residential land and even the area of commercial housing. Tax revenue and interest rate controls were also put into place. ${ }^{5}$ Starting from late 2006, as liquidity in the market continued to increase and the 'bidding, auctioning and public tender' policies for land leasing were widely implemented, land and housing prices soared further and new records for land-leasing prices were set every few days. None of the four consecutive interest rate increases by the central bank in 2007 was able to stem the rapid rise in housing prices. It was only in 2008, with the arrival of the GFC, that housing prices in China started to decrease. In the first quarter of 2009, housing prices dropped by 1.1 per cent.

5 Since 2003, the Chinese Government has put forward a myriad of control measures, including the ' 121 Document', the 'New and Old Eight Opinions', the 'Six Opinions' and the 'Fifteen Opinions' issued by the State Council, including the implementation of the 'three-step' approval process for controlling land as well as the push to build economised housing and low-rent housing, implementing financial and taxation rules such as eliminating low interest rate home loans, increasing down payments on new homes and levying transactional taxes on second-hand properties. Despite the implementation of these measures, housing prices continued to rise quickly and new highs continued to be set. 


\section{Investment platform boom and local debt accumulation after 2008}

The central leadership is well aware of the potential problems associated with this development model and has attempted to steer the Chinese economy towards growth largely driven by domestic consumption. The reality is, however, more complicated. The old model has created its own vested interests and these actors - central and local, public and private - forged a strong growth coalition to perpetuate the existing path. The post-GFC episode illustrates this dynamic. In the aftermath of the GFC, Chinese exports dropped by more than 20 per cent in the second half of 2008 and early 2009. The Chinese Government's response was prompt and massive. It pledged RMB4 trillion in fiscal spending in two years as well as increasing bank credits by RMB9.6 trillion in 2009 and RMB7.95 trillion in 2010. The irony is that, instead of boosting consumption, the stimulus money reinforced the existing imbalance in the Chinese economy and further distorted land-use patterns in urbanisation. Flooded with cash, local governments initiated more ambitious industrial park construction and became more aggressive in attracting manufacturing businesses. Land leases for industrial purposes reached 0.14, 0.15 and 0.19 million ha in 2009, 2010 and 2011, respectively, which exceeded the pre-crisis level of 0.136 in 2007. Giant state-owned corporations, the other major beneficiaries of the stimulus, splurged on business expansion, including huge purchases of mines both domestically and in the global market. Both contributed to further build-ups in manufacturing in China. On the other hand, local governments' urbanisation schemes were kept buoyant by easy credit as well as speculative funds. Landlease prices reached new highs as real estate developers chased the limited quantity of available land. The centrally controlled SOEs also invested heavily in the real estate sector and in many cases they overbid substantially, fuelling a real estate bubble. In many third or fourth-tier cities, housing prices more than doubled within one to two years. Local governments cashed in on land development, and lease fees doubled from RMB1.59 trillion in 2009 to RMB3.15 trillion in 2011. These revenues, combined with land-backed bank loans and bond sales, enabled local governments to launch massive urban infrastructure projects, such as railways, subways, roads and airports.

The GFC not only failed to shift China's primary driver of growth from investment to consumption, but also heightened the risk of a potential crash of the Chinese financial system due to overinvestment that built more overcapacity in manufacturing and industrial-related infrastructure. Worldwide recession and its associated protectionism have already put a damper on China's export growth, and rapid expansion in the future is unlikely. Massive investments in manufacturing and infrastructure really hinge on continual revenue flows from the housing and real estate sectors. Instead of becoming an alternative engine for Chinese growth, super-high property prices actually suck up the savings of the middle class and weaken their demand for other goods. Moreover, local 
governments' addiction to land revenue and intention of propping up the markets have invited rampant speculation and contributed to the build-up of a huge asset bubble. Like Japan and the United States in the past, in China, this game of musical chairs will have to end at some point. When the bubble bursts, local governments will lose the main source of income they have used to binge on industrial parks and infrastructure construction. The immediate shock to China's financial system will be devastating. Once land and housing values plummet, state banks will bear the brunt of easy credit and trillions of loans may turn into non-performing assets on their balance sheets.

\section{Social impacts of China's land-based urbanisation}

Economic imbalance aside, this developmentalism has also had a devastating impact on society. Over-leveraging land for development has caused social and political problems.

First, the rapid rise in housing prices and the formation of a real estate bubble over the past decade have made it impossible for the majority of rural migrant populations to afford commodity housing in cities. In fact, even the new entrants into the labour force with university degrees find that today's housing prices are far more than what they can afford. Clearly, this has become a major challenge for China to realise full urbanisation and urban-rural integration. In urban areas, residents are overburdened with skyrocketing housing prices. The red-hot housing market not only drained people's financial resources for consumption, but also carried the huge risk of a bubble (Su and Tao 2011).

Second, the great Chinese land grab has especially soured urban-rural relations. The need to generate revenue and subsidise manufacturing enterprises led to the twin problems of excessive requisition of farmland and undercompensation for landowners, resulting in millions of disgruntled farmers (Zhu and Prosterman 2007; Tao et al. 2010). Insufficient compensation for land requisition is now the primary reason for rural petitions and collective action by farmers against the state. A research report (China Land Problem Task Force 2007) estimates there were more than 40 million dispossessed farmers due to urban expansion and transportation projects. For a host of reasons but primarily because local governments tend to underpay, especially in light of soaring urban land prices, farmers losing their land are often dissatisfied with the amount of compensation. Moreover, under-compensated farmers who have lost their land easily become unemployed but generally have limited access to urban welfare benefits. A 17-province, 1962-farmer survey conducted in China in 2005 shows the number of land-related incidents increased more than 15 times during the past 10 years and appeared to be accelerating. In the first nine months of 2006, China reported a total of 17900 cases of 'massive rural incidents', in which 
a total of 385000 farmers protested against the Government. Approximately 70 per cent of these incidents were related to illegal land-taking. In some areas, land disputes have resulted in mass incidents and have greatly undermined social harmony. ${ }^{6}$ And this is only the tip of the iceberg, as many Chinese peasants do not even protest when their land is taken away. The problem is so widespread that one commentator notes that an 'economic war is going on at the local level in China today especially on the fringes of expanding urban areas' (Subrahmanyan 2004).

\section{Dualism in land management and rural collective land-use inefficiency}

Under the current system, markets for urban and rural land have been artificially divided. A market-oriented reform for rural collective land is badly needed to improve both efficiency and equity in China's land use. The rising illegal use of land throughout the country and the spontaneous emergence of a rural construction land market in many localities indicate that the current land management system is no longer functioning under an increasingly marketoriented economy (Han 2003).

Special attention needs to be paid to China's rural residential land, which accounts for a majority of China's rural construction land. Under China's land management system, every rural household is eligible to apply for one, and only one, piece of residential land on which a house can be built for accommodation purposes.

Given the huge number of rural households (around 200 million) in China, residential land constitutes one of the most important land-use types in rural areas - next only to farmland. According to the first national land cadastral survey conducted in 1996, rural settlement occupied 164558 ha of land, which was 6.21 times as high as urban settlements and which accounted for 68.4 per cent of all settlement and industrial/mining land (240 753 ha) (Lin and Ho 2005). More recent census data also showed that the total area of rural residential land reached 166000 ha by the end of 2004-4.88 times the land taken up by urban construction uses (34000 ha). This implies that per capita rural residential landholdings are $214 \mathrm{sq} \mathrm{m}-64 \mathrm{sq} \mathrm{m}$ higher than the standard defined by the National Village and Township Planning Standards.

6 According to statistical data from 2005, there were nearly 80000 mass incidents nationwide, of which 30 per cent were to defend the rights of farmers, while 70 per cent of these cases were because of unfair compensation for land that had been reallocated. Of the more than 74000 mass incidents examined on the CCTV program Topics in Focus in 2005, 15312 were related to land disputes. Most of these were conflicts that arose because of the low price paid by local governments in reallocating the land. Later, land-related disputes rose to 60 per cent (Yu Jianrong 2006). 
Unlike urban housing properties, however, rural residential properties, including the land and the housing unit, are still strictly regulated and cannot be traded freely on the market. It is alleged that the policy of allocating one piece of residential land for every rural household, but disallowing trading beyond the village, helps secure farmers' housing rights in an egalitarian way while at the same time protecting the country's limited arable land resources. Given the sheer size of rural residential land in China and the rural house-building craze in the reform era, both the Government and academia have continually expressed worries that rural residential land and its expansion 'may have contributed greatly to the loss of farmland in China' (Ho and Lin 2003). Since village housing accounted for about 5-6 per cent of the total area forfeited and the area lost to new housing was greatest in the central eastern provinces-traditionally a highly productive agricultural region (Sargeson 2002; Ash and Edmonds 1998) - these worries seem reasonable. As a result of policy tightening, rural residential land transactions beyond village boundaries have been completely prohibited since 1998. If any such transaction occurs, it would be illegal and thus no land and housing certificates would be issued.

The strict regulations on residential land use and transactions have met serious challenges in policy implementation. The main challenges come from the country's large-scale migration and rapid urban expansion, which generated land-use problems both in China's vast agriculture-based countryside and on the fringes of cities where urban expansion is fastest and where demand for residential land is intensive. In the agricultural areas far away from the city, such a challenge is mainly manifested in the fact that residential land continues to encroach on arable land while at the same time residential land-use efficiency remains low, since a large number of farmers leave their housing idle - that is, the phenomenon of 'hollow villages'. In suburban areas and even within cities, many 'suburban villages' and 'urban villages' have emerged and provide affordable housing for a great number of migrants.

\section{Idle house sites and hollow villages in pure farming areas}

Between 1996 and 2006, rural residential land accounted for 80 per cent of the 1 million mu (1/15 hectare) of newly occupied arable land due to rural construction. In the context of urbanisation, although an increasing number of farmers are earning higher incomes through off-farm employment, they are still unable to settle in cities on a permanent basis under China's household registration system (hukou). Since the rural population cannot be effectively reduced through permanent migration, and at the same time rural residential land cannot be traded freely beyond villages, local governments and rural community organisations have to allocate more land for residential housing construction when new families are formed in villages. This usually means 
occupation of existing farmland. At the same time, a significant share of existing rural residential properties are either underutilised or left totally idle as a large number of migrants go to cities. In many of the agricultural regions one can find hollow villages. Based on a survey of 119 villages, 59 townships and 30 counties across six provinces including Jilin, Hebei, Shaanxi, Sichuan, Jiangsu and Fujian in 2008, Wang et al. (2010) present the following interesting findings: first, for the surveyed 2230 rural families, 34 families (1.52 per cent) have no residential property, while 1965 families (88.1 per cent) own one residential property. Although government policy states that one and only one rural residential property can be allocated to each rural family, the survey shows that 231 families (10.36 per cent) possess two or more residential properties. Second, the average area of land occupied by residential property in rural China is $288 \mathrm{sq} \mathrm{m}$ per residential property. ${ }^{7}$ Third, the higher the share of outmigration in a village, the more likely the village is to have a higher ratio of vacant residential properties. This relationship tends to be consistent with the general observations that people who leave their villages for urban jobs may leave their housing properties in the villages underused or even idle. Fourth, the average ratio of vacant residential properties was as high as 7.5 per cent for the six provinces. Among all of the 119 villages, there were 14 villages that had vacancy rates higher than 20 per cent, and seven villages with vacancy rates higher than 30 per cent. Finally, while there are significant shares of vacant housing in rural villages, new residential house-building continues to occupy arable land. Since 1978, on average, the share of residential housing built by occupying arable land has been more than 20 per cent of all the new residential building and this share was still as high as 23.4 per cent during the 1999-2008 period. In other words, on average, more than one-fifth of residential housing construction in rural China occupied arable land.

\section{'Urban villages' and 'small-property-rights housing'}

In contrast to hollow villages and inefficient residential land use in China's agricultural areas, many 'urban villages' and much 'small-property-rights housing' have emerged in China's suburban areas and even within cities. These are the locations where the value of rural collective land appreciates fastest due to booming demand for housing. Under current laws, only the state has the right to expropriate collectively owned rural land and then lease it to urban users.

7 Jilin Province had the largest area of residential land (511 sq m per residential property) on average, followed by Hebei Province (347 sq m per residential property). Jilin Province also experienced a steady increase in the average land area for rural residential property, with a more than 45 per cent increase from 1978 to 2008. As for the whole nation, the survey data revealed that the average size of the land taken for residential use had dropped slightly from the 1980s to the 1990s, but increased about 9 per cent afterwards despite the implementation of the so-called 'strictest' regulation for farmland protection in China. 
Since expropriation of rural collective land by the state is often carried out with very low compensation, it is no surprise that farmers and village collectives on the urban fringe have strong incentives to engage in rent competition with the urban authorities, who monopolise urban land supplies ( $\mathrm{Zhu}$ and $\mathrm{Hu} 2009$ ). Informal land developments thrive on China's urban fringes, including the rapid development of a housing rental market targeting migrant farmers in urban villages and the fast growth of 'small-property-rights' housing.

Housing rental markets on urban fringes boomed largely due to the influx of a floating population of migrant workers. Limited by the hukou system, the floating populations have no access to public housing, nor are they eligible for the urban affordable housing programs that target urban permanent residents. Though in theory purchasing urban commercial housing is an option, rural migrants usually cannot afford the high prices. Moreover, without urban hukou, many in the floating population regard their presence in the cities as temporary; therefore they tend to minimise their living expenditure in cities, thus renting and sharing housing in the urban villages and suburban areas become their major housing choices. As a result, many suburban villages in China have become so-called 'migrant enclaves', or urban villages in which migrant workers from the countryside concentrate. It is estimated that at present around half of the 140-150 million migrant workers are living in around 50000 urban and suburban villages in cities.

Under China's current land and hukou system, rapid migration inevitably leads to a large population of migrants living in 'urban villages'. The landlords of the urban villages (farmers who own the residential properties) can earn considerable income by renting out their houses. In this sense, the urban villages have played a significant role in China's urbanisation process. They not only provide affordable housing when urban governments fail to provide housing security for migrants, but also generate income for the landlords in urban villages whose arable land has already been requisitioned by local governments for urban expansion. This largely offsets the negative impacts of land requisition, which usually pays inadequate compensation. Therefore, one needs to recognise the important value of urban villages for two of the most vulnerable groups in China's urbanisation: the floating population and the dispossessed farmers. Certainly, the emergence of urban villages may have some negative consequences. Since local governments cannot obtain revenue from such land and housing development projects, they have no incentive to improve the infrastructure and public services in urban villages, thus environmental conditions in these localities are usually very poor and sometimes crime rates are also very high compared with other urban spaces under government control. 
Precisely because urban villages provide dispossessed farmers with considerable income, urban redevelopment and renovation projects that target these urban villages are usually very difficult to implement. When the compensation to landlords in urban villages fails to reflect the opportunity costs of their rental income, strong opposition to local government moves to demolish and redevelop urban villages occurs. Unfortunately, as housing prices have skyrocketed in Chinese cities in recent years, many city governments and real estate developers now find demolishing urban villages an increasingly profitable business. Urban village demolition is being carried out in many cities across the country. Social unrest due to unfair compensation easily follows. The questions to ask, then, are: if urban villages are demolished, how can the dispossessed farmers (the landlords of urban villages who already lost their arable land) make a living since they can no longer receive the rental income to maintain their livelihood? Moreover, where can the large number of migrants find shelter if they are forced out of urban villages?

Besides urban villages, 'small-property-rights' housing is also booming in China's city fringes. Small-property-rights housing is the commodity housing developed either by village collectives or by farmers themselves for which ownership certificates are not issued by urban governments. These housing units may not be legally transacted on the market. Small-property-rights housing can refer either to the large-scale apartment buildings developed on rural land for sale or to the small-scale rural residential housing properties owned by individual rural households and then sold to people from outside villages. As a result of local governments' monopolisation of land supply in urban areas, land and housing prices have skyrocketed in the past decade. It is natural for the rural collectives and farmers to start commercial real estate development for profit on collectively owned land. Though there is no legal protection and the Government has issued many prohibitive policy documents, the growth of small-property-rights housing is just amazing. An estimate of the total construction area of small-property-rights housing suggests that by the end of 2007, it had reached 6.4 billion sq $\mathrm{m}$, accounting for 17 per cent of the country's total urban housing stock (Wang and Tao, 2009) ).

\section{Land requisition and limited reform so far}

\section{Land requisition in China}

Nowhere is the question of using public power to acquire land for private investment more prominent than in China, where, due to Chinese land laws, typically the only way land can become available for private investment is through a process of land requisition. Both the Chinese Constitution and the 
1999 Land Administration Law (LAL) specify that the state, in the public interest, may lawfully requisition land owned by collectives, thus setting the stage for compulsory land acquisition. ${ }^{8}$

There is, however, no clear definition of 'public interest' in the law and in practice local governments acquire land from farmers and then either use it for infrastructure development and public projects such as public schools and hospitals or lease it to industrial and commercial/residential developers. According to the Land Administrative Law amended by 1998, 'all land used for urban development, as well as the land used for energy, transportation, water conservancy, mining and military projects outside the urban land use planning boundaries, if it needs to be taken from rural collectives, has to be acquired through the formal government land requisition process'. Moreover, decisions with regard to whether to acquire the land, how much land to acquire and the compensation and resettlement packages for land-taking are all to be made by the city and county governments unilaterally. Local governments only need to provide a Land Acquisition Notice and a Land Compensation Notice within 10 working days of the approval of a land-taking plan by upperlevel governments - that is, either the provincial government or the Central Government, depending on the scale of land-taking (Ministry of Land and Resources 2001:Art. 3). The notice is a procedure to be fulfilled after the landtaking approval and after the compensation decisions have been made. Farmers whose land is to be acquired would only be informed about the decision and they would then be asked to register their names with the relevant government agency to deal with compensation and resettlement issues.

Land development in urbanisation is a complicated process because it requires first acquiring the land, then converting it to state ownership, resettling the displaced farmers and providing urban infrastructure before finally leasing the land to developers. It also involves the interactions of multiple players in land acquisition including individuals, corporations and governments. In China, the acquisition of new land for urban expansion is largely controlled by government officials through a process in which officials requisition land from nearby villages and pay compensation determined by the value of agricultural production, the value of land improvements and other factors as specified by law (Ho 2005; Ding 2007; Lichtenberg and Ding 2008). Under the current system, land acquisition is to be carried out without much, if any, participation of and negotiation with farmers. No land-taking contract needs to be signed with the rural collectives and

8 In 2004, Article 13 of the Chinese Constitution was amended to give constitutional protection to private property rights. It provides that ' $[\mathrm{t}]$ he state may, for the public interest, expropriate or take over private property of citizens for public use, and pay compensation in accordance with the law'. This protection is echoed in Article 2 of the Land Administration Law, which was amended after the aforementioned constitutional amendment. The Chinese Constitution merely mentions compensation without any requirement that it be just. 
its members whose land will be taken. The rural collectives and farmers affected by the land acquisition can only dispute the level and contents of compensation and resettlement packages, but not the land acquisition itself. According to the 1998 LAL and its 'Detailed Rules for Implementation' enacted in 1999, disputes about compensation and resettlement should not affect the land requisition process and the final decision about land compensation is to be made by county and city-level governments. ${ }^{9}$ Chinese law provides only that the farmers affected are to be informed about land requisitioning and the compensation to be paid (LML 48). Thus, farmers are not involved in bargaining about the compensation amount and have no formal legal instrument for stopping land acquisition when they do not agree with the amount of compensation offered. ${ }^{10}$

Since the county and city-level governments are the same actors that implement land acquisition, it is difficult for them to make a fair arbitration when there are disputes about the compensation. Local courts also tend to ignore the lawsuits against local governments with regard to land requisition and the excuse is usually that the individual farmers are not the owners of the land. ${ }^{11}$ Dispossessed farmers usually have to resort to petitions to the upper-level government or even engage in confrontational collective actions against local governments. In most cases, such protests are directed not against land grabbing but against the compensation farmers are to receive.

9 Under the 1986 Land Administrative Law, the state can acquire land for 'public interests' though there are no clear definitions of public interests. Article 13 of the 1986 LAL, however, stipulates that disputes about land use must be negotiated by the relevant parties and the final decision is to be made by the local governments at and above the county level; if any party involved is not satisfied with the Government's decision, it can file a lawsuit with the local court within 30 days of being informed of the Government's decision. Before the dispute is resolved, either by government decision or by the court, no party involved may change the status quo of land use. In other words, regulations from the 1980 s stipulate that land users need to negotiate with rural collectives about the quantity of land to be acquired and the compensation and resettlement package, and sign land acquisition contracts.

10 Even the existing procedure is not well implemented, as recent research found only 20 per cent of the farmers whose land was acquired had received the required prior notice about compensation (Zhu et al. 2006). This shows that even if negotiations were required by law, many land developers would still be able to start construction without following procedure, whether it was a duty to provide information, as at present, or a duty to enter into negotiation, introduced in the future.

11 Initiating civil or administrative litigation against unlawful behaviour of land developers or local government has not been used much or with much success (van Rooij 2007). The nationwide data on legal redress for land-takings demonstrated that only 0.9 per cent of aggrieved farmers filed a lawsuit for more compensation (Zhu et al. 2006). Clearly, going to court has not been a preferred option for landgrab victims. The chances of winning a case against a local government or against land developers with good local connections are slim. Courts are paid and partly managed by their local governments and have tended not to bite the hand that feeds them. In addition, the context of judicial corruption and personal favours (guanxi) further denies poor peasants success in the courtroom. Courts, like lawyers, have refused to take on land cases, claiming they lack jurisdiction or that litigants do not have the right to stand (Phan 2005:18). 
Even in the 2007 Property Rights Law, not much progress was made in protecting farmers from abusive land-taking. The law only stipulates that the 'government can acquire rural collective land for the purpose of public interests according to law and following the legal process', and still there is no clear definition of 'public interests'. As to the compensation and resettlement package, the law only vaguely stipulates 'compensation for the land itself; resettlement subsidies; and compensation for improvements to the land and for crops growing on the requisitioned land need to be paid in full. Social security payments should be arranged for the dispossessed farmers so that their livelihood [can] be maintained and their legal rights [can] be fully protected.' ${ }^{12}$

As securing cheap land for local governments to attract businesses became increasingly important after the mid 1990s, local officials had strong incentives to depress land compensation to farmers, which further pressured local officials into direct confrontation with farmers whose land was the target of forceful requisition. While this pressure applied to all municipal and county-level officials, the stress on township cadres was particularly acute. Sitting at the bottom of the local government hierarchy, they were responsible for almost all matters related to rural society. The municipal or county governments might set land development plans and propose terms for land requisition, but township officials were the ones who would carry out difficult negotiations with village collectives and were in charge of coercing defiant farmers to accept governmentset terms. Having village cadres who shared their interests would not only lower the requisition costs, but also may determine whether or not the transaction could be accomplished at all. If the deal failed, their superiors would discount their leadership credentials, thus jeopardising their future career.

Therefore, township officials in localities that experienced a higher intensity of land requisition had stronger incentives to manipulate the rules to make sure that more cooperative cadres were elected. Drawing on two national surveys, recent research by Su et al. (2013) offers strong empirical evidence of the impacts of land-taking on Chinese Villagers' Committee (VC) elections. As shown in their analysis, there are no uniform rules in VC elections and villages have relied on different formulas to elect their leaders. Some rules are more transparent and democratic, but others leave a lot of grey areas that are open to manipulation. In villages with more intensive land requisition, electoral rules are more

12 The LML provides for a standard of compensation six to ten times the annual average output value of the three preceding years and a resettlement fee of four to six times average annual output. The law also provides absolute combined compensation maxima of no higher than 15 times annual output, or when approved by provincial authorities no higher than 30 times the annual output of the land compensated. The specific standards are determined at the provincial level. Both village committees and farmers are to be consulted about requisition compensation. Compensation payments must be made public, and the new law explicitly states that it is forbidden to embezzle or divert compensation funds (LML, ss. 47, $48,49)$. 
likely to be manipulated by their upper-level governments. For example, local government may intervene into the formation of election committees by appointing members of the committees, or they can intervene in the nomination of candidates so that they can pick their own favoured individuals.

Besides intervening in village elections to pick the 'right' cadres, local governments also have multiple other instruments to incentivise village officials to be on their side in the land acquisition process. Various economic incentives are used to induce cooperation from the village cadres. This can happen because the village collective is the basic socioeconomic organisation in rural areas, and its largest asset is the land collectively owned by its members. Even though China's laws recognise that both the collective and its members should be entitled to share compensation, there are no specific policy guidelines or regulations on how to divide the shares in different situations. In practice, among the three types of land compensation for acquisition - that is, compensation for the land itself, resettlement subsidies and compensation for improvements to the land and for crops growing on the requisitioned land-compensation for the land itself is usually paid to the village collective. Therefore, village cadres may benefit from land acquisition. In some localities such as Shanghai, rural collectives can share stock in the land they transfer for projects. In return, they receive annual cash payments equivalent to average profits from farming, which they can use. In other places such as Suzhou, local governments leave some non-agricultural land to the village collectives for non-agricultural development and thus the village cadres are able to obtain revenue simply by renting out the allocated land for non-agricultural purposes. Therefore, in the process of land acquisition, local cadres have strong incentives to cooperate with local governments or even the land users rather than the villagers, since the collective organisation and the cadres can benefit in terms of economic returns.

If local governments can influence village elections to elect cooperative village cadres and have multiple economic instruments to induce village cadre collaboration, it is very difficult for the land acquisition process to be transparent so farmers know very clearly when and how much of their land will be acquired and how much they will be compensated. Lack of transparency easily leads to corruption and a lack of legal channels for farmers to file appeals and protests against governments in compulsory land acquisition cases. The issues of accountability and transparency therefore figure prominently in land acquisition in which village cadres usually work together. Misappropriation of compensation funds for land and indulging in fraudulent means to acquire land from the farmers is inevitable (Ding 2007; Subrahmanyan 2004). 


\section{Limited reforms so far}

For China's current development and urbanisation model to work, local governments must have access to a lot of cheap land to compete for the mobile manufacturing land users. Luckily, Chinese local governments are empowered by the present land requisition and leasing systems almost as the monopolistic player in land-taking, preparation and leasing processes.

An amendment to the Constitution in 2004 provides that the state may carry out land requisition to serve the public interest in accordance with the law and appropriate compensation will be made. The concept of 'public interest' has, however, not been clearly defined by relevant laws and regulations, such as the Constitution and the Land Management Law. In practice, not only does the land used for urban infrastructure construction need to be requisitioned from rural collectives, but also land for industrial, commercial and residential developments is prepared through government requisition. In the process, local governments generally have the power to decide the compensation standards. Concerning the compensation for land-taking, both the owners (rural collectives) and the users (individual rural households) of rural land are in a weak position.

For their own interests, local governments inevitably have strong incentives to set low compensation standards. Our fieldwork in recent years revealed that even in some developed areas dispossessed farmers received only very low cash compensation while at the same time there was no social security provided for them. Since a fair number of dispossessed farmers are poorly educated, they may easily become unemployed after land requisition. While some localities have started to implement a social security policy for dispossessed farmers (known as the 'land for social security' policy), its conditions are still set by the local government. Dispossessed farmers usually lack any negotiation power about the scope and the level of social security benefits. Some areas even use the 'land for social security' policy as a means to avoid short-term government fiscal obligations by promising dispossessed farmers certain social security benefits in the future. In this way, governments are able to obtain huge revenue by land leasing while at the same time delaying paying out social security benefits until a later date (Wang and Tao 2009).

Over the past 10 years, the majority of China's suburban areas have witnessed massive urban expansion, along with a fast-growing number of dispossessed farmers. In recent years, the scale of land requisition has reached approximately 3 million mu every year. If we assume per capita farmland is $1 \mathrm{mu}$ in suburban China, this means that around three million farmers lose their land each year. By 2006, the total number of dispossessed farmers exceeded 40 million and this number will increase to 70 million in the next 10-15 years (Tianze Economic Research Institute 2007). 
To address the challenges from excessive industrial land leasing and abusive land requisition practices by local governments, the State Council and the Ministry of Land and Resources in the past several years have issued a series of policies and regulations aimed at local governments. These include the elimination of industrial parks and strengthening land supervision as well as requiring local governments to lease land through more market-oriented approaches. ${ }^{13}$ According to our fieldwork across the country, however, the central policies have rarely been implemented because of intense regional competition for manufacturing investment. The local strategy in response to the Central Government directive is what has been called 'designated bidding, auctioning and public tender' - that is, local governments usually set a series of conditions for participating companies to constrain competition in land leasing, so they can lease the land to a preselected industrial company. Therefore, enforcing a policy that requires the 'bidding, auction and public tender for industrial land leasing' is essentially ineffective. This is because this policy is unable to eliminate the root cause of intense regional competition for manufacturing investment.

The Central Government has also attempted to reform the land requisition system by raising compensation standards for land-taking and by limiting the scope of land requisition. The Central Government is now amending the Land Administration Law and has also issued the 'Measures for Public Notification of Land Requisition', so as to stop local governments from abusively taking farmland and infringing farmers' property rights. Due to fiscal pressure from the taxsharing reform in 1994, however, local governments had no choice but to rely on the cheap transfer of industrial land to compete for manufacturing investment, while at the same time earning profits from leasing out commercial/residential land to support urban industrial park and infrastructure development. As long as local governments set the compensation criteria, it will be impossible to establish a good mechanism that can protect the property rights of dispossessed farmers. While short-term measures implemented by the Central Government to contain abusive land requisition and raise compensation for land-taking may help, the high monitoring costs and the unwillingness of local governments to cooperate will render such policies ineffective. Certainly, this does not imply that the Central Government should be responsible for setting compensation criteria

13 For example, requirements are specified in the Circular of the State Council on Intensifying Land Control (No. 31 [2006] of the State Council): 'industrial land shall be leased by means of public bidding, auction and public tender and by strictly following the procedures and methods prescribed in the Provisions on the Assignment of State-owned Lands by Means of Bidding, Auction and Public Tender and the Rules on the Assignment of State-owned Lands by Means of Public Bidding, Auction and Public Tender.' And, this 'is of great significance to strengthening macroeconomic control, strictly controlling land use and effectively controlling the total land; to bringing down the competition by lowering industrial land prices and overexpansion of industrial parks, and realizing value preservation and appreciation of state-owned assets; to establishing a functioning land market mechanism and to improving land use efficiency.' 
for land requisitions at the local level. In a country as large as China, putting the land compensation setting power in the hands of the Central Government would not make much sense. A final solution to this problem requires a fundamental reform of the land management system.

The latest amendment of the Land Management Law (LML) serves as a good example of the limitations of reform so far. In 2009, the Ministry of Land and Resources came up with a highly controversial draft LML amendment. In the draft, the articles related to land requisition have been amended significantly. Compared with the existing LML, a new chapter on 'land expropriation and requisition' is added to standardise the scope and procedure of land requisition. The key idea is to restrict government power and narrow the scope of land requisition, as well as provide social security for dispossessed farmers.

Even though these changes demonstrate the Government's determination to improve the current land requisition system, the new draft LML still prescribes that 'within the urban construction area defined by the Land Master Plan, the state can requisition collective land for construction use according to the city planning', whether the land is used for public purposes (such as land for infrastructural development) or for non-public purposes (such as land for industrial, commercial and residential use). Only in areas beyond the urban construction area defined by the Land Master Plan' can rural collectives develop land for non-public purposes on their own.

Such a constraint on rural land development is inevitably problematic. First, it implies that the majority of rural land with high value for non-agricultural use will still need to go through the land requisition process even if the land is used for non-public purposes. In fact, this is in line with the interests of local government. If such a definition has not been made, local government will only be able to requisition the land that serves public interests such as land used for infrastructural development, public education and public health institutions. Then local governments will no longer be able to requisition land from farmers and lease it out for industrial, commercial and residential purposes.

Moreover, local governments may easily expand the 'urban construction area defined by the Land Master Plan' by adjusting land-use planning. This is evident in the implementation of the 1997-2010 Master Plan: the more economically developed one locality is, the more frequent are the planning adjustments. Although in principle the preparation, implementation and adjustment of the land-use planning need to go through a public hearing process, in reality there has been little public participation. If the aforementioned article of the LML amendment is adopted, it will be very difficult to placate farmers who 
live within the 'urban construction area defined by the Land Use Master Plan'. This, in turn, could lead to confrontations between local governments and farmers (Wang and Tao 2009).

Reducing the scope of land requisition and allowing rural collectives to develop land for industrial, commercial and residential uses on their own are two sides of one coin. If the rural collectives and farmers are allowed to develop rural land on their own, it would imply that such land development does not need to go through the process of state requisition preparation leasing. Therefore, progress in land requisition reform largely determines the progress in rural collective land reform.

For a long time, Chinese academia has been arguing for rural collectives and farmers to be granted the rights to develop collective land for non-public purposes. In 2007, China enacted a Property Law. The law has an element providing 'equal property rights protection for both the rural collective land and the state-owned land'; however, if no fundamental reform is carried out in China's land requisition system, it is extremely difficult to imagine that rural collective land can ever enjoy equal treatment in development. In this sense, land requisition system reform is a prerequisite for rural collective construction land reform.

Reducing the scope of government land requisition and allowing rural collectives to develop collective construction land on their own would not only contribute to limiting the development zone craze witnessed across the country and enhance land-use efficiency in China's urbanisation, but also help farmers on city fringes to share some benefits of urbanisation by engaging in land development. Our fieldwork in the past several years in the Yangtze River Delta, the Pearl River Delta, North China Plain and Chengdu-Chongqing area indicates, however, that the opposite is happening. Indeed, local governments in many localities, rather than limiting the scope of land requisition, have begun to demolish existing urban villages and requisition more land from urban suburbs so as to continue the distorted land-based urbanisation. Acquiring more land from urban villages to be leased to real estate developers not only generates substantial land revenue for city governments, but also helps to improve the physical image of the cities. Certainly, these requisition and demolition actions are often met with serious confrontation between farmers and the local government. 


\section{Towards a new model of urbanisation with coordinated reforms focusing on land}

As detailed in the preceding sections, the complex challenges China faces in the course of urbanisation and economic development are closely related to China's land system. To address the distortions in urbanisation and help China to complete its great economic transformation, the Government must be resolved to carry out fundamental land reforms. Only by implementing real land reform and coordinating this with reforms to hukou and local public finance can the unsustainable model of urbanisation be rectified.

\section{Reform of the land requisition system}

A reform of the land requisition system needs to strictly define public versus non-public use of land. In other words, for land requisition to be considered legal, expropriated land must be designated for public use. In defining 'public', we believe that if a product manufactured on a piece of land is produced for market consumption then the land use itself should also be decided by the market. Only products that cannot be provided by the market, whether profitable or not, should be seen as public projects and land requisition applies.

Even for land requisition that targets public use, the Government should ensure that compensation is based on fair competition. No matter what the purpose of the project, citizens should not suffer loss from land requisition. Besides, compensation for land based on market values is an internationally recognised principle. At this point, it is worth looking at the methods the Beijing Municipal Government has used.

1. Provincial governments set minimum compensation criteria at the municipal and county levels for land expropriated within their jurisdictions. These criteria should not violate the 'law of one price', and should be based on the overall evaluation of local economic and social conditions such as land resources, production level, geographical condition and the supply-demand relationship, and so on.

2. Establish a negotiating mechanism between governments, developers, village collectives and local farmers.

3. Design a scientific land requisition system and a negotiation and arbitration mechanism in land requisition compensation, which are independent of the municipal or county government. 


\section{Reform of the collective construction land system}

A decision by the Third Plenary Session of the Seventeenth Congress of the Chinese Communist Party (CCP) in 2007 stipulated that the scope of market transactions for collectively owned land should be gradually expanded. Based on the current revised draft of the Land Administration Law, however, lawmakers tend to constrain the location where farmers can obtain non-agricultural development rights on their own land. In another world, only farmers could develop on their own the land outside the defined scope of urban construction land. This regulation would, however, mean the vast majority of rural land with market value (within the defined scope of urban construction land) still needs to go through the land requisition/land preparation/land-leasing process and farmers could not develop it. This would also mean continued restrictions on commercial/residential development on collective land. The Chinese Government is apparently worried about losing control of construction land use; however, these policies have not been implemented well, as not only does 'small-propertyrights housing' continue to flourish, the Government also has lost tax revenue that could have been collected if such properties had been legalised.

Granting development rights on collectively owned land not only would help to protect the interests of those with rights to the land, thus reducing social conflict, but would also be good for improved land-use efficiency. With regard to the widespread issue of small-property-rights housing, standardising and guiding the development of such properties in the amendment of the Land Administration Law would be preferable to an outright ban. As long as it is not against public interests and is in line with overall land use and urban planning, this land should be transferred to state-owned status and the development rights to most of the land should be given to the original property rights-holder. This would be the only way towards realising the law of one price between collectively owned and state-owned land. Under this model, both industrial and commercial developers could deal directly with village collectives or farmers, while the Government could be compensated by requiring developers to pay a standard transfer fee and/or charging a value-added tax on the land. In this way, while ensuring that a portion of the increased value of land goes to the Government, the village collectives and farmers, as holders of transferable land with a high potential for appreciation, could maintain the agricultural value of their land and a certain portion of the land value appreciation throughout this transition.

The implications of land reform would go far beyond simply providing reasonable compensation to dispossessed farmers. It would be essential to stabilise and even lower the high prices of residential land monopolised by local governments, and thereby control the corresponding skyrocketing housing prices. It would also be essential to stop local government from expropriating 
land at low prices and then building large-scale industrial parks. It would be essential for China to address the land-use distortions and the serious social conflicts due to abusive local land requisition. If these reforms can be implemented along with corresponding land-use planning adjustments, the issues of protection of farmland and excessive urban expansion would be addressed effectively. With the introduction of tax reforms, local government would also be compensated for the shortfall of land-leasing revenue.

\section{Large-scale public housing versus market-based land reform for housing security}

One key issue in China's urbanisation is to accommodate the huge migrant population in affordable housing. The Central Government is currently demanding that local governments increase the supply of public housing; however, due to the massive investment required, there is a serious lack of incentives for local governments. A more fundamental issue is whether any country could cover the floating population of 200 million people and their families with public housing and whether this is the best way to address the housing problems for the newly urbanised (Tao and Xu 2006, 2007).

In a global context, a healthy real estate development model is one in which public housing is targeted mainly at individuals at the lowest income levels who are not even able to afford market rental rates. The majority of people, whether through purchasing or renting, should be sheltered through market-provided housing. If the market price is so high that the Government has to provide a large proportion of mid to low-income households with public housing, reforms will be needed to address the prices.

The concept of 'affordable housing', in broad terms, can refer to housing provided by any entity for mid and low-income groups. This naturally includes public housing provided by local governments for low-income families who cannot afford to rent or purchase a home. This does not, however, necessarily mean that government needs to provide the housing directly, nor does it imply the creation of a welfare society in terms of housing. If the market can provide the majority of the population with housing that they can afford to rent or buy then housing affordability has been realised. As an example, in the Pearl River Delta region, where housing is relatively expensive, 40-50 per cent of the migrant population lives in dormitories, while the remaining floating population lives in rented housing within urban or suburban villages. While a majority of the rental housing is illegal small-property-rights housing without decent infrastructure or public services, it has provided migrant workers with a place to live with their families. In fact, experiences in Pearl River Delta cities such as Guangzhou, Shenzhen, Foshan and Dongguan show how local farmers 
and village collectives in suburban areas can proactively share the benefits of urbanisation and how they can provide affordable rental housing to migrants. In Shenzhen alone, half of the seven million migrants live in urban villages. In 2005, 327000 people with local hukou lived permanently in these urban villages, while temporary residents totalled almost 4.7 million, or 14 times the number of permanent residents. According to the Shenzhen Municipal Housing Construction Plan 2006-2010, of the 250 million sq $\mathrm{m}$ of homes in the city, 120 million sq $\mathrm{m}$ belong to original village residents or village collectives. Of these, private homes concentrated in urban villages cover an area of $95 \mathrm{sq} \mathrm{km}$ (8 sq km within the special economic zone, or SEZ), with a total construction area of about 100 million sq $\mathrm{m}$ (20 million sq $\mathrm{m}$ within the SEZ).

In the course of China's urbanisation, the primary cause of the housing bubble is that local governments monopolise and undersupply land for residential use. Therefore, besides building some public housing or providing rent subsidies to low-income groups, allowing collectively owned construction land in suburban and urban villages to gradually enter the market is essential. Not only can local farmers build housing to share some of the land value appreciation in urbanisation, but also the hundreds of millions of migrants can be accommodated without much government expenditure.

\section{Urban village redevelopment and coordinated land, hukou and fiscal reform}

We propose that addressing the housing bubble and providing the migrant population with affordable housing in China can be achieved by innovative models of urban and suburban 'village' redevelopment. This will not only increase land-use efficiency, but also promote social equity.

The issue of redeveloping 'urban villages' deserves more elaboration here. At present, the common practice in most cities is to demolish these villages and lease the land out to commercial and residential developers after requisitioning the rural collective land as state-owned land. This not only leads to social conflicts in urban village redevelopment programs, but also drives away the migrant workers who find urban villages the only affordable housing sites in cities. Therefore, it is hardly a sustainable model of urban village redevelopment. 
An alternative approach is to learn from the successful experiences of land value capture, land readjustment ${ }^{14}$ and urban land consolidation ${ }^{15}$ from the United States, Japan, South Korea and Taiwan. A land readjustment scheme is typically initiated by the municipal government designating an area that is about to be developed. A subdivision plan is developed for unified planning of the area. Provision of infrastructure and services is financed by the sale of some of the plots within the area, often for commercial activities. The original landowners are provided with plots within the reshaped area, which, although smaller, now have access to infrastructure and services. ${ }^{16}$

The redevelopment and renovation of China's urban villages can draw on these successful international land readjustment experiences and further innovate by taking into account China's specific conditions to provide affordable housing for migrants from the countryside. This can be done by requiring, through urban planning, the landowners of urban villages develop rental housing rather than commodity housing. The floor-area ratio can be lifted in these readjustment projects by the city planning authority. If such practices can be extended to a sufficient number of urban/suburban villages, the supply of rental housing would be adequate and rental prices can be kept reasonable even after urban village redevelopment. In this way, affordable housing can be provided for the huge floating population through market mechanisms rather than through direct government provision of public housing.

In fact, allowing farmers in urban and suburban 'villages' to build housing for non-local migrant populations - once proper planning, infrastructure and government taxation are in place - would not only imply a breakthrough in China's land reform, but also facilitate China's ongoing hukou reform. Once the issue of housing for migrants can be addressed effectively and public schools can be built for migrants' children in these redeveloped urban villages, an effective breakthrough in household registration reform would be realised.

14 'Land readjustment' refers to a situation when, after having expropriated and redeveloped an area of land, the Government takes a portion of the land for infrastructure use, another portion for public auction to cover the cost of land development, and the remaining portion (with a much higher plot ratio) mostly for returning to the original land rights-holders.

15 'Urban land consolidation' is a method by which, according to the development needs of a city, areas within urban planning zones, areas of urban-rural fringe zones or urban outskirts, sections of land that are irregular and poorly organised as well as areas that are overcrowded and not suitable for economic use are redeveloped under government order and reallocated to coordinate with public facilities, improving roads, parks, squares and rivers. Once it has been ensured that all plots of land are of a suitable size and square with a certain scale, they are reallocated to the land rights-holder. This guarantees that urban land is used more efficiently and economically, creating a clean and orderly urban environment.

16 A definition of the technique is provided by Archer (1987): 'Land readjustment is a technique whereby a group of neighboring landowners in an urban-fringe area are combined in a partnership for the unified planning, servicing and subdivision of their land with the project costs and benefits being shared between the landowners.' 
The underlying economics can be illustrated by the following example. Assume an urban 'village' covers a land area of 100 units owned by 200 village households. During the course of redevelopment, local government first engages in direct negotiations with the village collective. After calculating the potential value added to the property after the redevelopment, the Government can requisition 45 units of land from the villagers. Of the 45 units taken by the Government, 30 can be used for infrastructure development in redevelopment while the remaining 15 units can be sold via public auction to cover the cost of infrastructure construction. Meanwhile, even though the original land rights-holders have given up 45 units, the remaining 55 units may still have higher value with better infrastructure and higher floor-area ratios granted by the Government. By extrapolating from this simple example, we can design a series of steps to implement coordinated reform in land, household registration and the local tax system.

First, in terms of the legal system and policy implementation, the land on which urban villages are built can be converted to state-owned land first; however, the Government will not grant land-use rights to a third party such as a real estate developer but to the original land rights-holder - that is, the urban villagers.

Second, in terms of development and financing, once the villagers are issued the certificates of state-owned land-use rights, they can work together to apply for a bank mortgage or bring in private funds to begin redevelopment on their own. With this funding, villagers can develop rental housing to accommodate migrants and other low and medium-income residents in cities.

Third, the land value appreciation in rural-urban land conversion can be largely attributed to the 'positive externality' generated by urban growth and infrastructure investment; there is therefore an economic rationale for the Government to take a certain share of land for free. The land can be used for infrastructure development and financing.

Fourth, the Government can in principle levy a tax on the rental income of urban villagers and, in the long run, a property tax on housing stock can be introduced to further consolidate local tax bases. Local government may use some of the tax revenue to pay for the education of migrants' children in newly built urban public schools.

In essence, the proposed reform allows rural communities in urban/suburban villages of migrant-receiving cities to take their non-farming land onto the urban housing market if these communities are willing to submit some of their land to local government for infrastructure development. One further condition 
is that for the first 10-15 years, they can only build properties used for rental purposes. After the transitional period, however, these houses would gain full rights and can be sold directly on the housing market.

This design has a number of advantages. Insulating rural construction land in the rental market initially provides a cushion for the existing housing market and prevents market panics and a crash of the housing bubble. On the other hand, eventually merging the two tracks in the future sends a credible signal to speculators that housing prices will not rise further; therefore, the Central Government can phase out its strict regulations on real estate markets installed since 2010 to curb the housing bubble. Both contribute to healthy growth of the housing market. Moreover, granting rural communities development rights (even though restricted during the transition) opens the legal channels for them to apply for bank loans for development. This can unleash a housing construction boom in urban villages and suburban areas, which provides a lift for construction-related industries with significant overcapacity. Finally, unlike the current housing bubble, this kind of real estate development is more socially beneficial and economically sustainable. Rural residents, particularly those living close to urban centres, benefit from this change directly. The growth in the rental property track also makes housing affordable for hundreds of millions of migrant workers, enabling them to settle in cities permanently. Urbanisation holds the potential of turning the Chinese economy away from an investmentdriven model.

The key to the success of the proposed reform lies in the attitude of local governments. Their concern over revenue is legitimate and needs to be addressed in the reform package. Under the current system, local governments are burdened with too many spending responsibilities but do not have adequate revenue. After the reform, they will have limited power of land requisition and lose the sizeable land-lease fees and bank loans associated with that power. In the long run, property taxes should be levied so that local public finance can be supported by a stable source of income. Considering the strong resistance from the wealthy and the politically powerful in the trial cities, it is unrealistic to expect this new tax to take effect soon; however, the loss of revenue during the transitional period will be compensated by several sources.

First, the urban and suburban villages that are lured by the huge rents to join the proposed rental market track would be prepared to contribute some of their land for free to local governments in return for their newly gained land development rights for rental housing. The land readjustment technique proposed earlier is an effective way for government to capture the land value appreciation in urbanisation. Local governments would then be able to spare themselves having to pay for infrastructure improvement from their own budgets. In addition, the proposed rental income tax could be used to cover 
the education expenditures for migrants' children in urban public schools. Once China is able to accommodate hundreds of millions of migrants on a permanent basis, they would work, live and consume like urban residents - a further boost to domestic demand.

Second, for those rural communities that have already developed their land 'illegally' for urban usage, a gradual process of legalisation can be started if certain infrastructure and building standards are met and due taxes are paid. The land and house owners would be willing to pay local governments to gain full legal status.

Finally, another untapped source for local governments is underutilised industrial land. According to various reports, the floor-area ratio in China's industrial parks is only about 0.3-0.4, even in China's developed areas. Through reorganisation by negotiation, it is possible to double the land development intensity of industrial land use so that local governments can work with industrial land users to convert some industrial land to residential and commercial uses. Between 1997 and 2009, the area of industrial land increased by $15000 \mathrm{sq} \mathrm{km}$ - that is, 22.5 million mu. This means if the floor-area ratio in China's industrial parks can be doubled to 0.6-0.8, at least 10 million mu of industrial land can be used for residential and commercial purposes. In fact, as cities expand, the location of much land in industrial parks becomes valuable for residential and commercial development. If this kind of land conversion can be gradually implemented with planning adjustment, at least 1 million mu of industrial land should be available for residential and commercial development each year. One way to make this happen is to allow industrial land users to redevelop their land for residential and commercial purposes, either by themselves or by working with real estate developers, on the condition they pay the difference between land-leasing prices for industrial purposes and for residential/commercial purposes. Assuming RMB750 000/mu for housing and commercial land (the 2008 price) and assuming local governments take only two-thirds of the revenue, local governments can collect RMB500 billion per year for the next 10 years. If we further assume that two-thirds of this converted land is used for housing, with a floor-area ratio of 1.5, about 600 million sq $\mathrm{m}$ of housing would be built each year. With a moderate price of RMB5000/sq $\mathrm{m}$ under the current tax system, local governments can raise RMB420 billion in real estate-related taxes. Therefore, even with some moderate assumptions, local governments can be largely compensated even if they gradually phase out land requisition for non-public uses. The key is to adjust the land-use structure of existing urban land by intensifying the use of industrial land and converting some underutilised industrial land to residential and commercial purposes. 
If this can be done, local governments can use some of the revenue to pay for the debts incurred through local financial platforms. Their resistance to land requisition reform would be much weaker.

\section{Conclusions}

In China's land reform, as in any reform, strategy matters. Gradualism can assist selection of the right sequencing so reforms make good economic sense and also can generate enough political support to overcome resistance. In our view, a reform package that centres on land and urbanisation provides the best chance of unleashing huge domestic demand and relieving the overcapacity problem in many industries in China.

China should focus on land reform because land has played an essential role in the making of China's growth model in the past 15 years, and it is also responsible for current woes in the economy. Even though China's land-based development model contributed to the dramatic rise of the Chinese economy, the negative consequences are also numerous and obvious.

Changing course is hard. The old model has created its own vested interests and these actors - central and local, public and private - have forged a strong growth coalition to perpetuate the existing path. In the aftermath of the GFC, the prompt and massive response from the Chinese Government reinforced the existing imbalance in the economy.

Despite tremendous inertia, some reform in land can no longer be postponed. A gradualist approach is proposed that aims to build a dual-track system. Under the current land regulatory regime, land ownership is separated into urban and rural, and only urban governments have the authority to take land from rural areas for urban development. This not only deprives rural residents of their development rights but also leads the Chinese economy down a quite destructive path. Total liberalisation, however, may result in a crash of the existing housing bubbles if large volumes of rural construction land are rushed onto the market. To alleviate this concern by local governments and urban homeowners, China may need to first set up a rental property market track targeting mainly the 200 million rural migrants who already choose to live and work in cities. This could be done by redeveloping urban/suburban villages so that local farmers in these villages can legally build rental housing for migrants. The land readjustment technique can be employed to ensure such land development conforms to urban planning and infrastructure development criteria. Government can also levy rental income tax and, in the long run, property tax so as to finance urban public services such as education for migrant children. To make up for the potential revenue shortfall due to this reform, 
local governments in China can also convert some industrial land for residential and commercial construction and levy a tax on land value appreciation from such conversion. This would not only alleviate the revenue concerns of local government, but also help to reduce the distortions in China's urban land-use structure.

At the current stage of development and transition, no reform in the Chinese economy is going to be easy. One certainly should not have any illusions about a quick fix. The proposed land reform package may, however, offer some hope of transitioning into a more healthy urbanisation model, boosting domestic consumption and alleviating the overcapacity problem in many industrial sectors. One particularly favourable factor of this reform is the new leadership's emphasis on a new urbanisation model by making real breakthroughs in reforms. What China needs now is a realistic road map for such reforms.

\section{References}

Archer, R. W. (1987), Transferring the urban land pooling/readjustment technique to the developing countries of Asia, HSD Working Paper No. 24, Human Settlements Development Programme, Asian Institute of Technology, Bangkok.

Ash, R. and Edmonds, R. L. (1998), 'China's land resources, environment and agricultural production', The China Quarterly (156): 840-52.

China Land Problem Task Force (2007), Implementation and Protection of Land Property Rights in Urbanization, Beijing: Unirule Economics Institute.

Ding, C. (2007), 'Policy and praxis of land acquisition in China', Land Use Policy 24: $1-13$.

Ding, C. and Lichtenberg, E. (2011), 'Land and urban economic growth in China', Journal of Regional Science 51: 299-317.

Han, J. (2003), 'Change collective land ownership into shareholder ownership', China Economic Times, 11 November, [in Chinese].

Ho, P. (2005), Institutions in Transition: Land Ownership, Property Rights and Social Conflict in China, New York: Oxford University Press.

Ho, S. P. S. and Lin, G. C. S. (2003), 'Emerging land markets in rural and urban China: policies and practices', The China Quarterly 175: 681-707. 
Huang, J., Tao, R., Xu, Z. and Liu, M. (2008), Institutional Change and Sustainable Development: China's Agricultural and Rural Development for 30 Years, 30 Years of China's Reform Series, Shanghai: People's Publishing House.

Huang, X. (2007), 'An in-depth analysis of current land issues', Economic Perspective (2).

Johnston, B. and Mellor, J. (1961), 'The role of agriculture in economic development', American Economic Review 51: 566-93.

Lichtenberg, E. and Ding, C. (2008), 'Assessing farmland protection policy in China', Land Use Policy 25: 59-68.

Lichtenberg, E. and Ding, C. (2009), 'Local officials as land developers: urban spatial expansion in China', Journal of Urban Economics 66: 57-64.

Lin, C. S. and Yi, F. (2011), 'Urbanization of capital or capitalization on urban land?', Urban Geography 32: 50-79.

Lin, G. C. S. (2007), 'Reproducing spaces of Chinese urbanisation: new citybased and land-centred urban transformation', Urban Studies 44: 1827-55.

Lin, G. C. S. and Ho, S. P. S. (2005), 'The state, land system, and land development processes in contemporary China', Annals of the Association of American Geographers 95(2): 411-36.

Lin, Y., F. Cai and Zhou, L. (1999), China's Miracle: Development Strategy and Economic Reform, Shanghai: People's Publishing House.

Ministry of Land and Resources (2001), Regulations on Land Acquisition Notices, Beijing: Ministry of Land and Resources.

Ministry of Land and Resources (2006), Final Report from the Workshop on Industrial Land Price Evaluation and Analysis, September, Beijing: Ministry of Land and Resources.

National Development and Reform Commission (NDRC), Ministry of Land and Resources and Ministry of Construction (2006), An Audit Report of Development Zones in China, Beijing: NDRC, Ministry of Land and Resources and Ministry of Construction.

Phan, P. N. (2005), 'Enriching the land or the political elite? Lessons from China on democratization of the urban renewal process', Pacific Rim Law and Policy Journal 14: 607-57. 
Qian, Y. (2000), 'The process of China's market transition (1978-98): the evolutionary, historical, and comparative perspectives', Journal of Institutional and Theoretical Economics 156(1): 151-71.

Sargeson, S. (2002), 'Subduing “the rural house-building craze': attitudes towards housing construction and land use controls in four Zhejiang villages', The China Quarterly 172: 927-55.

Stark, O. (1991), The Migration of Labour, USA: Blackwell.

Tao, R. and Wang, H. (2009), 'On "Zhejiang model" of the transfer and trade of land development rights - system origin, mode of operation and its important meaning', Management World (September).

Tao, R. and $\mathrm{Xu}, \mathrm{Z}$. (2005), 'Urbanization, agricultural land system and social security for migrant workers: policy options from the perspective of a large developing country in transition', Journal of Economic Research (12): 45-56.

Tao, R. and Xu, Z. (2006), 'Groping for stones to cross river versus coordinated policy reforms? The case of two reforms in China', Journal of Policy Reform 9(3): 177-201.

Tao, R. and Xu, Z. (2007), 'Urbanization, rural land system and social security for migrant farmers in China', Journal of Development Studies 43(7): 1301-20.

Tao, R., Su, F., Liu, M. and Cao, G. (2010), "'Race to the bottom." Competition by negotiated land leasing: an institutional analysis and empirical evidence from Chinese cities', CEMA Working Papers, No. 294.

Tao, R., Lu, X., Su, F. and Wang, H. (2009), 'China's transition and development model under evolving regional competition patterns', Journal of Economic Research (7): 21-34.

Todaro, M. (1969), 'A model of labour, migration and urban unemployment in less developed countries', American Economic Review 59(1): 138-48.

Tsui, K. and Wang, Y. (2004), 'Between separate stoves and a single menu: fiscal decentralization in China', China Quarterly 177: 71-90.

van Rooij, B. (2007), 'The return of the landlord: Chinese land acquisition conflicts as illustrated by peri-urban Kunming', Journal of Legal Pluralism (55): $211-44$. 
Wang, H. and Tao, R. (2009), 'How to achieve systematic breakthrough in the land requisition system reform-proposal to "Land Management Law Amendment"', Leader (29).

Wang, H., Tao, R., Wang, L. and Su, F. (2010), 'Farmland preservation and land development rights trading in Zhejiang, China', Habitat International 34(2010): 454-63.

World Bank (2002), China National Development and Sub-National Finance: A Review of Provincial Expenditures, Washington, DC: The World Bank.

World Bank (2005), China: Land Policy Reform for Sustainable Economic and Social Development, Washington, DC: The World Bank.

$\mathrm{Wu}, \mathrm{W}$. (2010), ‘Urban infrastructure financing and economic performance in China', Urban Geography 31: 648-67.

Xinhua News Agency (2010), 'Wasteful industrial land use in China is significant', Xinhua News Agency, 7 March. Available from <http://news.xinhuanet.com/ legal/2010-03/07/content_13113869.htm>.

Zhai, N. and Xiang, G. (2007), 'An analysis of China's current land acquisition system and policy implications', China Administration 3, [in Chinese].

Zhu, K. and Prosterman, R. (2007), 'Securing land rights for Chinese farmers: a leap forward for stability and growth', Cato Development Policy Analysis Series (3).

Zhu, K., Prosterman, R., Jianping, Y., Ping, L., Riedinger, J. and Yiwen, O. (2006), 'The rural land question in China: analysis and recommendations based on a 17-province survey', New York University Journal of International Law \& Politics 38: 761-839. 
This text taken from Deepening reform for China's long-term growth and development, edited by Ligang Song, Ross Garnaut, Cai Fang, published July 2014 by ANU Press, The Australian National University, Canberra, Australia. 